\title{
A MULTI PROXY ASSESSMENT OF LONG-TERM ANTHROPOGENIC IMPACTS IN PATOS LAGOON, SOUTHERN BRAZIL
}

\section{Carolina Bueno ${ }^{*}$, Rubens Figueira ${ }^{2}$, Michel Doeppre IVANOFF ${ }^{3}$, Elirio ERnestino Toldo Junior ${ }^{3}$, LAURA FORNARO ${ }^{4}$ AND FELIPE GARCÍA-RODRÍGUEZ ${ }^{4,5}$}

1 Universidad de la República, Facultad de Ciencias, Oceanografía y Ecología Marina, Instituto de Ecología y Ciencias Ambientales, Montevideo, Uruguay

2 Universidade de São Paulo, Instituto Oceanográfico, Laboratório de Química Inorgânica Marinha, São Paulo, Brazil

3 Universidade Federal do Rio Grande do Sul, Instituto de Geociências, Centro de Estudos de Geologia Costeira e Oceânica, Porto Alegre, Brazil

4 Universidad de la República, Centro Universitario Regional del Este, Rocha, Uruguay

5 Universidade Federal do Rio Grande, Instituto de Oceanografia, Programa de Pós-Graduação em Oceanología, Rio Grande, Brazil

\section{*CORRESPONDING AUTHOR, cbueno@fcien.edu.uy}

Received on 11 July 2018

Received in revised form on 09 August 2019

Accepted on 13 August 2019

\section{Editor: Maria Virgínia Alves Martins, Universidade do Estado do Rio de Janeiro}

\section{Abstract}

Sediments preserve environmental information at the time of deposition which is a useful tool to evaluate the extent of the environmental change from its pristine condition. We evaluated historic environmental trends in the sedimentary record by analysing three sediment cores collected within the freshwater region of Patos Lagoon (southern Brazil). As, Ba, $\mathrm{Cr}, \mathrm{Cu}, \mathrm{Ni}, \mathrm{Pb}$, and $\mathrm{Zn}$ were analysed by inductively coupled plasma optical emission spectrometry. $\mathrm{C} / \mathrm{N}$ ratios and $\delta^{13} \mathrm{C}$ values were also determined. Contamination indices such as Enrichment Factor, Geoaccumulation Index, Sediment Pollution Index and Pollution Load Index were calculated to evaluate the influence of anthropic activities. Multipleelemental indices showed a general overview of the environmental conditions of the lagoon throughout time. Furthermore, single-element indices explained which elements triggered the observed changes in the environmental trends. Near Camaquã River mouth, we inferred fairly undisturbed conditions and did not seem to be affected by the mining activities upstream Camaquã River. The influence of these activities was observed upstream the lagoon, between Camaquã and Guaíba rivers, probably as a

\section{Introduction}

Understanding the main integrated processes occurring in aquatic systems is the key to an accurate evaluation and management. However, for most of the aquatic systems long-term historical environmental information is rarely available (Skilbeck et al., 2005). In this sense, the advantage
Citation:

Bueno, C., Figueira, R., Ivanoff, M.D., Toldo Junior, E.E., Fornaro, L., García-Rodríguez, F.G., 2019. A multi proxy assessment of long-term anthropogenic impacts in Patos Lagoon, southern Brazil. Journal of Sedimentary Environments, 4 (3): 276-290.

consequence of the hydrodynamics of the lagoon. Especially, $\mathrm{As}, \mathrm{Ba}$ and $\mathrm{Pb}$ showed moderately polluted levels after 2009 AD. In Guaíba site, a progressive deterioration of the lagoon quality was observed after 1980 reaching the worst environmental degradation by 2000 AD. However, Enrichment Factor values only showed moderate pollution levels suggesting a considerable dilution process within the system given its large size. Similar $\delta^{13} \mathrm{C}$ signature was observed in the whole lagoon prior to the anthropogenic influence. However, such a condition changed differentially after the anthropogenic fingerprint. Recent sediments reflected a shift in the plant cover, and particularly in Guaiba, the influence of urban and industrial activities of Porto Alegre City were reflected in the sedimentary record. Overall, metals together with organic matter composition proxies allowed us to determine the anthropic-related changes in Patos Lagoon.

Keywords: Heavy Metals. $\delta^{13} \mathrm{C}$. Anthropic Impact. MultiProxy Approach. Pollution Indices. Coastal Area.

of sediments in the assessment of environmental status is that they preserve information of the environmental conditions at the time of deposition. Depending on the resolution aims, sediments are appropriate to assess environmental changes at scales of variability of hundreds or even thousands of years of undisturbed information 
(Skilbeck et al., 2005; Birch, 2007; 2017; Birch and Olmos, 2008). As there is no single parameter suitable to explain the spectrum of conditions prevailing during the sedimentation process, a multi-proxy approach provides a sound and reliable holistic overview of environmental change (Smol, 2007).

In order to evaluate the magnitude of human-induced changes, it is necessary to assess background levels to determine to what extent the environment has changed from its pristine condition. In this sense, a widely used set of proxies to assess past environmental conditions is the concentration of trace metals throughout a sediment core (Birch, 2017). The metalloid Arsenic (As) and trace metals such as Barium (Ba), Chromium $(\mathrm{Cr})$, Copper $(\mathrm{Cu})$, Lead $(\mathrm{Pb})$, Nickel (Ni) and Zinc ( $\mathrm{Zn})$, among others, are either naturally found in aquatic systems or transported as a consequence of anthropogenic processes. All these elements are toxic (over threshold levels) with potential negative effects on biological populations, even at low concentrations (Sutherland, 2000; Mirlean et al., 2003; Birch, 2013). The organic matter content stored in the sediments, as well as its isotopic signature, also helps to reconstruct past environmental conditions such as hydrologic flows and sedimentary processes, including anthropogenic modifications to the natural system (Meyers, 2003). In particular, sedimentary $\mathrm{C} / \mathrm{N}$ ratios and $\delta^{13} \mathrm{C}$ values in the organic matter, retain source signatures which remain preserved over long periods of time despite some possible early diagenetic modifications (Meyers, 1994).

Patos Lagoon located in southern Brazil, is the world's largest choked coastal lagoon. It exhibits two different regions: the freshwater and the estuarine zone. The estuarine boundary is set by Ponta da Feitoria close to Pelotas City, 70 $\mathrm{km}$ away from the connection to the Atlantic Ocean (Moller et al., 1996). Due to its ecologic and economic significance, the estuarine region has been deeply studied based on different variables such as stocks and sources of carbon (Patterson, 2016), metals in sediments (Niencheski et al., 2004a), dissolved inorganic nutrients, organic pollution (Niencheski et al., 2004b), eutrophication, phytoplanktonic, zooplanktonic and ichthyofauna communities (Odebrecht et al., 2010, 2013), among others. However, the freshwater region of the lagoon (beyond Ponta da Feitoria) is less studied and only few data are available. For this region, studies are mainly focused on artisanal fisheries (Kütter et al., 2008; Ceni et al., 2016). Sedimentary metals were studied just for surficial sediments (Baisch and Wasserman, 1998), and the isotopic signature of the organic matter was analysed in order to provide information for trophic studies (Claudino et al., 2013). Furthermore, past environmental information or background levels for these variables are currently unavailable. Despite the ecological and economical importance of this area, this is the first analysis that considers the environmental quality and anthropic impact in the lagoon from a time-integrating perspective. Therefore, in the present work we attempt to infer historical human impacts from three sediment cores distributed within the freshwater zone of Patos Lagoon using the sedimentary elements: As, $\mathrm{Ba}, \mathrm{Cr}, \mathrm{Cu}, \mathrm{Ni}, \mathrm{Pb}$, and $\mathrm{Zn}$, as well as $\mathrm{C} / \mathrm{N}$ ratios and $\delta^{13} \mathrm{C}$ values as proxies.

\subsection{Study area}

Patos Lagoon ( $\left.30^{\circ} 13^{\prime} \mathrm{S}, 50^{\circ} 35^{\prime} \mathrm{W}-32^{\circ} 10^{\prime} \mathrm{S}, 52^{\circ} 061^{\prime} \mathrm{W}\right)$, with an area of $10,200 \mathrm{~km}^{2}$ is the world largest choked coastal lagoon (Kjerfve, 1986). It is located in Río Grande do Sul state, southeast of Brazil (Fig. 1). In the southernmost region, the lagoon is connected with the Atlantic Ocean through the Río Grande channel, creating an estuarine environment of great ecological complexity, with high biological productivity and great economic and tourist importance (Odebrecht, et al., 2013; Seeliger, 2004).

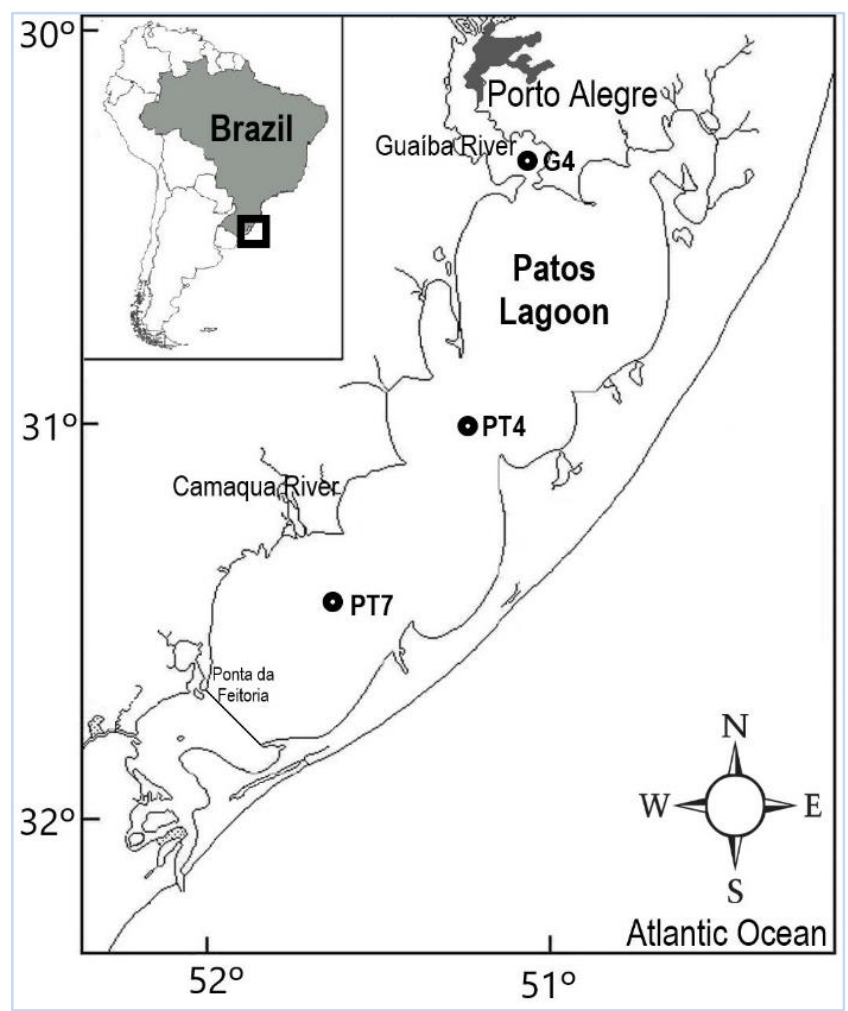

Fig. 1. Patos Lagoon located in southern Brazil. Line shows the boundary between the estuary and the freshwater region.

The discharge of the lagoon varies between 700 and $3000 \mathrm{~m}^{3} \mathrm{~s}^{-1}$, with a greater freshwater influence in winter and spring. During the years influenced by El Niño events, the flow entering the lagoon significantly exceeds the average values, with direct consequences on the biogeochemical processes of the sediments, and water circulation (Seeliger and Costa, 2002). The hydrodynamics of the lagoon depends mainly on the relationship between fluvial discharge and wind action (Moller et al., 1996; Fernandes et al., 2002). In southern Brazil, the influence of 
the Atlantic anticyclone causes the dominant north-eastern winds throughout the year (Stech and Lorenzzetti, 1992).

Regarding the sediment distribution, Patos Lagoon is dominated by silty facies, while clay facies are restricted to the southern region. In the transition zone between the main lagoon and the estuarine domain, both margins and the lagoon bed are covered by a wide deposit of fine sand (Calliari et al., 2009). Patos Lagoon is a sedimentary environment that receives freshwater with high concentration of suspended material from eight sub-basins, being the main contributors Guaíba and Camaquã rivers (Baisch and Wasserman, 1998).

The main activities near Guaíba River are concentrated in the urban area of Porto Alegre (the state capital with over 1.4 million people), where several industrial facilities are located, and use this river for effluent discharge (Dias Prestes and Quadros Rückert, 2017). On the other hand, Camaquã River drainage basin presents very low urban density where the only significant industrial activity is the exploitation of metallic sulphide minerals such as barite, pyrite, chalcopyrite, bornite and hematite (Baisch and Wasserman, 1998; Renac et al., 2014). Also, there has been an increased agricultural development in the area, with the irrigated rice production constituting one of the most important agricultural activity (Lima et al., 2011).

\section{Material and methods}

\subsection{Collection of samples}

All sediment cores were collected in February 2014. Sediment core G4 was collected in Guaíba River, near Patos Lagoon and cores PT4 and PT7 were collected in the freshwater zone of Patos Lagoon (Fig. 1). Cores characteristics and coordinates are shown in Tab. 1. All cores were longitudinally sectioned every $1 \mathrm{~cm}$ and samples were preserved in LaQIMar (Laboratório de Química Inorgânica Marinha), at Universidade de São Paulo, Brazil.

Tab. 1. Cores length, coordinates and depth of collection.

\begin{tabular}{|l|c|c|c|c|}
\hline Core & $\begin{array}{c}\text { Length } \\
(\mathbf{m})\end{array}$ & Latitude & Longitude & $\begin{array}{c}\text { Depth } \\
(\mathbf{m})\end{array}$ \\
\hline PT7 & 3.55 & $31^{\circ} 26^{\prime} 52^{\prime \prime S}$ & $51^{\circ} 40^{\prime} 10^{\prime \prime} \mathrm{W}$ & 6.44 \\
\hline PT4 & 3.79 & $31^{\circ} 01^{\prime} 55^{\prime \prime} \mathrm{S}$ & $51^{\circ} 18^{\prime} 04^{\prime \prime} \mathrm{W}$ & 5.69 \\
\hline G4 & 0.92 & $30^{\circ} 18^{\prime} 39^{\prime \prime} \mathrm{S}$ & $51^{\circ} 05^{\prime} 41^{\prime \prime} \mathrm{W}$ & 4.45 \\
\hline
\end{tabular}

\subsection{Geochronology}

Considering that Patos Lagoon is a very large and dynamic system, CRS model based on unsupported ${ }^{210} \mathrm{~Pb}$, which assumes a variable sedimentation rate (Appleby and Oldfield, 1983), was used for chronology assessment. The chronological model was validated with ${ }^{137} \mathrm{Cs}$ data. Analyses were performed in LaQIMar, Universidade de São Paulo,
Brazil. For this purpose, approximately $10 \mathrm{~g}$ of sediment were transferred into air-sealed cylindrical polyethylene containers for gamma counting in an EG\&G ORTEC® low-background gamma spectrometer (hyperpure Ge, model GMX25190P).

Sedimentation rate was calculated according to the following formula:

$$
V(z)=\lambda \frac{1}{\rho}\left(\frac{\left.\mathrm{I}\left({ }^{210} \mathrm{~Pb}_{\mathrm{xs}}\right) t-\mathrm{I}^{210} \mathrm{~Pb}_{\mathrm{xs}}\right) z}{\left({ }^{210} \mathrm{~Pb}_{\mathrm{xs}}\right) z}\right)
$$

Where: $\mathrm{V}(\mathrm{z})$ is the sedimentation rate at depth $\mathrm{Z}\left(\mathrm{cm} \mathrm{yr}^{-1}\right) \cdot \lambda$ is the decay constant of ${ }^{210} \mathrm{~Pb}\left(\mathrm{yr}^{-1}\right) \cdot \varrho$ is the sample density $(\mathrm{g}$ $\left.\mathrm{cm}^{-3}\right)$, calculated according to Ferreira et al. (2013). $\mathrm{I}\left({ }^{210} \mathrm{~Pb}_{\mathrm{xs}}\right) \mathrm{Z}$ is the ${ }^{210} \mathrm{~Pb}_{\mathrm{xs}}$ inventory from top to depth $\mathrm{Z}(\mathrm{Bq}$ $\left.\mathrm{cm}^{-2}\right) . \mathrm{I}\left({ }^{210} \mathrm{~Pb}_{\mathrm{xs}}\right) \mathrm{t}$ is the ${ }^{210} \mathrm{~Pb}_{\mathrm{xs}}$ inventory in the sediment core $\left(\mathrm{Bq} \mathrm{cm}^{-2}\right) .{ }^{210} \mathrm{~Pb}_{\mathrm{xs}}(\mathrm{z})$ is the ${ }^{210} \mathrm{~Pb}_{\mathrm{xs}}$ activity at depth $\mathrm{Z}\left(\mathrm{Bq} \mathrm{kg}^{-1}\right)$.

The quality control of the method was evaluated through the determination of the radionuclides ${ }^{210} \mathrm{~Pb},{ }^{226} \mathrm{Ra}$ and ${ }^{137} \mathrm{Cs}$ in three certified reference materials: IAEA-326 (soil), IAEA-327 (soil) and IAEA-385 (marine sediment).

\subsection{Metal determination}

Total digestion of the sediments was performed in LaQIMar (Laboratório de Química Inorgânica Marinha) at Universidade de São Paulo, Brazil following the EPA 3052 protocol (USEPA, 1996). The method consists of a microwave digestion with strong acids. First, $\mathrm{HNO}_{3}$ and then $\mathrm{HF}$ to completely dilute silicates (Loring and Rantala, 1992). Finally, $\mathrm{H}_{2} \mathrm{O}_{2}$ is added to completely eliminate organic matter. To evaluate the accuracy of analyses, the certificated reference material SS-2 EnviroMAT and blanks were analysed following the same protocol. The sample solutions were analysed by Inductively Coupled Plasma-Optical Emission Spectrometer (ICP-OES) Varian model 710ES. Detection limits are shown in Tab. 2.

\subsection{Organic matter proxies}

Samples free of carbonates (previously removed by acidification) were analysed for $\delta^{13} \mathrm{C}$ and total organic carbon (TOC). Bulk samples (not acidified) were used for total nitrogen (TN) analysis. Between 6 and $8 \mathrm{mg}$ of lyophilised sediments were placed in tin capsules and then analysed using a Thermo Scientific Delta V Advantage Isotope Ratio MS (EA-IRMS) coupled with a Costech Elemental Analyser at Universidade de São Paulo, Brazil. The reference standard for $\delta^{13} \mathrm{C}$ was the Vienna Pee Dee Belemnite (VPDB). The $\mathrm{C} / \mathrm{N}$ ratio was calculated considering the ratio between $\mathrm{TOC}$ and $\mathrm{TN}$ which will be here referred to as $\mathrm{C} / \mathrm{N}$ throughout the text.

\subsection{Indices calculation}

To investigate the influence of anthropogenic activities in Patos Lagoon, single-element indices: enrichment factor (EF) (Szefer et al., 1998) and Geoaccumulation Index (Igeo) 
(Müller, 1986) were calculated. Multiple-element indices were also applied: Sediment Pollution Index (SPI) (Singh et al., 2002), and Pollution Load Index (PLI) (Tomlinson et al., 1980).

Enrichment Factor (EF) was calculated according to Szefer et al. (1998) as follows:

$$
\mathrm{FE}=\frac{\left[\frac{\mathrm{C}_{\mathrm{X}}}{\mathrm{C}_{\mathrm{N}}}\right]_{\text {stratum }}}{\left[\frac{\mathrm{C}_{\mathrm{X}}}{\mathrm{C}_{\mathrm{N}}}\right]_{\text {base }}}
$$

Where: $C_{x}$ is the concentration of element $X$ and $C_{n}$ is the concentration of the normalising element.

In order to avoid the effect of grain size variability on metal concentration, data were element-normalised using Scandium (Sc). This element is associated with fine grained sediments and is considered a non-contaminating element
RESEARCH PAPER and rarely introduced to the environment by anthropogenic activities (Loring, 1988; Loring and Rantala, 1992).

Sediments were classified according to Sutherland, (2000) (Tab. 3) and the exception observed by Baisch and Wasserman, (1998) who established some levels of impact for Patos Lagoon at EF values higher than 1.

Geoaccumulation Index (Igeo) was calculated according to Müller (1986) following the equation:

$$
\text { Igeo }=\log _{2}\left[\frac{\mathrm{Cn}}{\mathrm{Bn} \times 1.5}\right]
$$

Where $\mathrm{Cn}$ is the concentration of metal $\mathrm{n}$ in the stratum and $\mathrm{Bn}$ is the basal concentration of the element. 1.5 is used to avoid possible changes in the concentration due to lithogenic variance.

Tab. 2. Reference and analytically obtained values for the reference certified material SS-2 EnviroMAT. For Method EPA 3052, Method Detection Limits (MDL) and Method Quantification Limits (MQL). SD - Standard Deviation. All values in $\mathrm{mg} \mathrm{kg}^{-1}$

\begin{tabular}{|l|c|c|c|c|c|c|c|c|c|}
\hline Element & $\begin{array}{c}\text { Reference } \\
\text { value }\end{array}$ & \multicolumn{2}{|c|}{$\begin{array}{c}\text { Confidence interval } \\
(95 \%)\end{array}$} & \multicolumn{2}{|c|}{ Tolerance interval } & $\begin{array}{c}\text { Average } \\
\text { obtained }\end{array}$ & SD & MDL & MQL \\
\hline $\mathbf{A s}$ & 78 & 62 & 94 & 5 & 151 & 72 & 9 & 0.53 & 2.66 \\
\hline $\mathbf{B a}$ & 650 & 594 & 706 & 380 & 920 & 419 & 24 & 0.11 & 0.55 \\
\hline $\mathbf{C r}$ & 58 & 51 & 65 & 21 & 95 & 43 & 3 & 0.12 & 0.60 \\
\hline $\mathbf{C u}$ & 198 & 189 & 207 & 155 & 241 & 158 & 12 & 0.19 & 0.95 \\
\hline $\mathbf{N i}$ & 59 & 55 & 63 & 42 & 76 & 43 & 5 & 0.24 & 1.19 \\
\hline $\mathbf{P b}$ & 148 & 130 & 166 & 63 & 233 & 89 & 8 & 0.40 & 1.98 \\
\hline $\mathbf{S c}$ & & & & & & & & 0.10 & 0.50 \\
\hline $\mathbf{Z n}$ & 509 & 479 & 539 & 362 & 656 & 420 & 34 & 0.39 & 1.93 \\
\hline
\end{tabular}

Tab. 3. Enrichment factor classification according to (Sutherland, 2000).

\begin{tabular}{|l|l|}
\hline EF Value & Classification \\
\hline $\mathbf{E F}<\mathbf{2}$ & $\begin{array}{l}\text { Minimal enrichment. Suggests null or } \\
\text { minimal contamination. }\end{array}$ \\
\hline $\mathbf{2}<\mathbf{E F}<\mathbf{5}$ & Moderate enrichment \\
\hline $\mathbf{5}<\mathbf{E F}<\mathbf{2 0}$ & Significant enrichment \\
\hline $\mathbf{2 0}<\mathbf{E F}<\mathbf{4 0}$ & $\begin{array}{l}\text { Very high enrichment, indicating high } \\
\text { level of contamination }\end{array}$ \\
\hline $\mathbf{E F}>\mathbf{4 0}$ & $\begin{array}{l}\text { Extremely high enrichment, indicating } \\
\text { extreme contamination }\end{array}$ \\
\hline
\end{tabular}

Considering the different values of Igeo, Müller (1986) proposed seven classes corresponding to different levels of sediment contamination (Tab. 4).

SPI is an index which integrates the relative toxicity of different metals, and was calculated according to Singh et al. (2002) following the formula:

$$
\mathrm{SPI}=\frac{\sum\left(\mathrm{EF}_{\mathrm{m}} * \mathrm{~W}_{\mathrm{m}}\right)}{\sum \mathrm{W}_{\mathrm{m}}}
$$

Where EF: enrichment factor of metal $\mathrm{m}$ in the sample, W: toxicity weight of metal $\mathrm{m}$ (i.e., $\mathrm{Cr}$ and $\mathrm{Zn}=1, \mathrm{Ni}$ and
$\mathrm{Cu}=2, \mathrm{~Pb}=5)$. According to the SPI values obtained, the sediments were classified into the categories established by Singh et al. (2002) (Tab. 5).

Tab. 4. Sediment classification according to the Geoaccumulation Index (Müller, 1986).

\begin{tabular}{|l|l|l|}
\hline Igeo Value & Class & Classification \\
\hline $\mathbf{<} \mathbf{0}$ & 0 & Unpolluted \\
\hline $\mathbf{0 - 1}$ & 1 & Unpolluted to moderately polluted \\
\hline $\mathbf{1 - 2}$ & 2 & Moderately polluted \\
\hline $\mathbf{2 - 3}$ & 3 & Moderately to strongly polluted \\
\hline $\mathbf{3 - 4}$ & $\mathbf{4}$ & Strongly polluted \\
\hline $\mathbf{4 - 5}$ & $\mathbf{5}$ & Strongly to extremely polluted \\
\hline $\mathbf{3} 5$ & $\mathbf{5}$ & Extremely polluted \\
\hline
\end{tabular}

PLI index was calculated following the equation proposed by Tomlinson et al. (1980):

$$
\mathrm{PLI}=\sqrt[n]{\mathrm{CF} 1 \cdot \mathrm{CF} 2 \cdot \mathrm{CF} 3 \cdot \ldots \ldots \cdot \mathrm{CFn}}
$$

Where: $\mathrm{CF}$ is the contamination factor for each metal, and calculated as $C_{s} / C_{b}$ (concentration in the stratum/base value concentration) 
According to these authors, this index provides a simple and comparative mean for assessing estuarine quality. A value of 0 indicates pristine conditions, 1 that only baseline levels of pollutants are present, and values higher than 1 would indicate progressive deterioration of the estuarine environmental quality.

Tab. 5. SPI classes established by Singh et al. (2002) and used in the present study.

\begin{tabular}{|l|l|l|}
\hline Class & SPI & Classification \\
\hline SPI0 & $0-2$ & Natural sediments \\
\hline SPI1 & $2-5$ & Low polluted sediments \\
\hline SPI2 & $5-10$ & Moderately polluted sediments \\
\hline SPI3 & $10-20$ & Highly polluted sediments \\
\hline SPI4 & $>20$ & Dangerous sediments \\
\hline
\end{tabular}

\subsection{Statistical analyses}

Correlations were assessed using the Pearson correlation coefficient. Box cox transformation and standardisation were previously performed to approach the data to a normal distribution.

\section{Results}

\subsection{Geochronology}

The age of the different intervals of the sedimentary profile was derived by utilizing the CRS model obtained from the ${ }^{210} \mathrm{~Pb}$ activities $\left(\mathrm{Bq} \mathrm{Kg}^{-1}\right)$ (Fig. 2).

According to the CRS model, the sedimentation rate of PT7 varied from 0.04 to $1.19 \mathrm{~cm} \mathrm{yr}^{-1}$, with an average of 0.44 $\pm 0.08 \mathrm{~cm} \mathrm{yr}^{-1}$. On the other hand, PT4 sedimentation rate ranged between 0.28 and $1.45 \mathrm{~cm} \mathrm{yr}^{-1}$ with an average of 0.55 $\pm 0.01 \mathrm{~cm} \mathrm{yr}^{-1}$. In $\mathrm{G} 4$, sedimentation rate varied between 0.04 and $1.08 \mathrm{~cm} \mathrm{yr}^{-1}$ with an average of $0.42 \pm 0,06 \mathrm{~cm} \mathrm{yr}^{-1}$.

In order to calculate the age of the entire sedimentary column, the years obtained for each core were adjusted to a third-degree polynomial equation $\left(\mathrm{R}^{2}\right.$ higher than 0.98 in all cases).

\subsection{Metal-based indices}

Values obtained from the reference material SS-2 EnviroMAT were always satisfactory and lied within the data-range recommended by the manufacturer (Tab. 5).

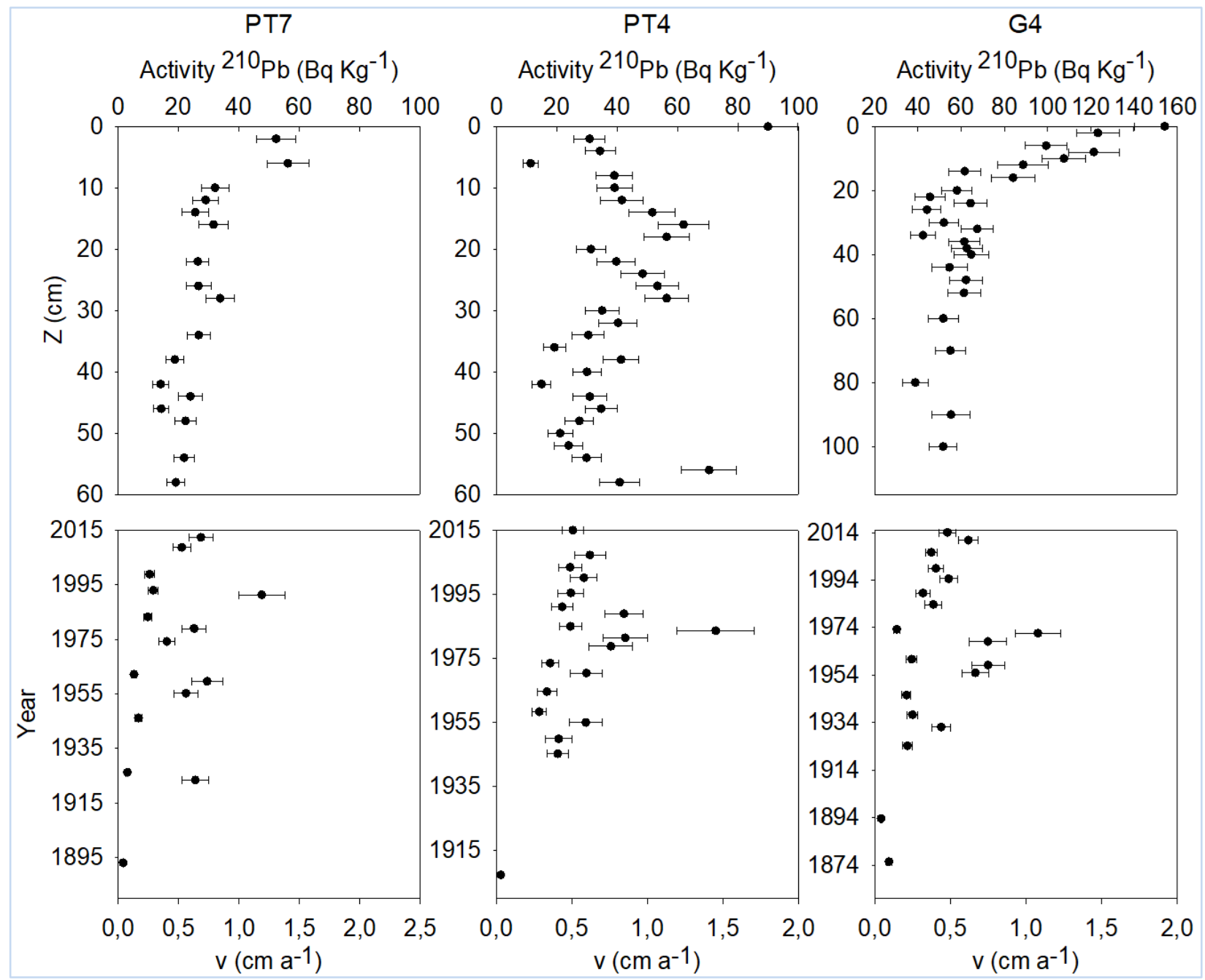

Fig. 2. ${ }^{210} \mathrm{~Pb}$ activities $\left(\mathrm{Bq} \mathrm{Kg} \mathrm{Kg}^{-1}\right)$ and accumulation rates $\left(\mathrm{v}\left(\mathrm{cm} \mathrm{yr}^{-1}\right)\right)$ for PT7, PT4 and G4. 


\subsubsection{Enrichment Factor (EF)}

Enrichment factor (EF) was calculated for the potentially contaminating elements: $\mathrm{As}, \mathrm{Ba}, \mathrm{Cr}, \mathrm{Cu}, \mathrm{Ni}, \mathrm{Pb}$, and $\mathrm{Zn}$ for each core. Results are shown in Figures 3, 4 and 5 for PT7, PT4 and G4 respectively.

In PT7, EF did not exhibit noticeable variation along the core, and the values for the different elements were close to 1 in all cases, except for a little variability observed between the 1940s and 1960s (Fig. 3).
RESEARCH PAPER

In PT4, values were close to 1 prior to 2009. After 2009, a constant increase was observed, reaching the highest EF value in 2015 for all elements (Fig. 4). In this sense, maximum detected $\mathrm{EF}$ values were: $\mathrm{As}=3.99, \mathrm{Ba}=4.43, \mathrm{Cr}$ $=1.69, \mathrm{Cu}=1.77, \mathrm{Ni}=1.61, \mathrm{~Pb}=2.46$ and $\mathrm{Zn}=1.69$.

In core $\mathrm{G} 4, \mathrm{EF}$ values were close to 1 until approximately 1989. Between 1990 and $2000 \mathrm{EF}$ reached the highest values for all elements, and after 2000 a slow decrease in the values was observed but remained fairly constant at levels higher than those of the baseline (Fig. 5).

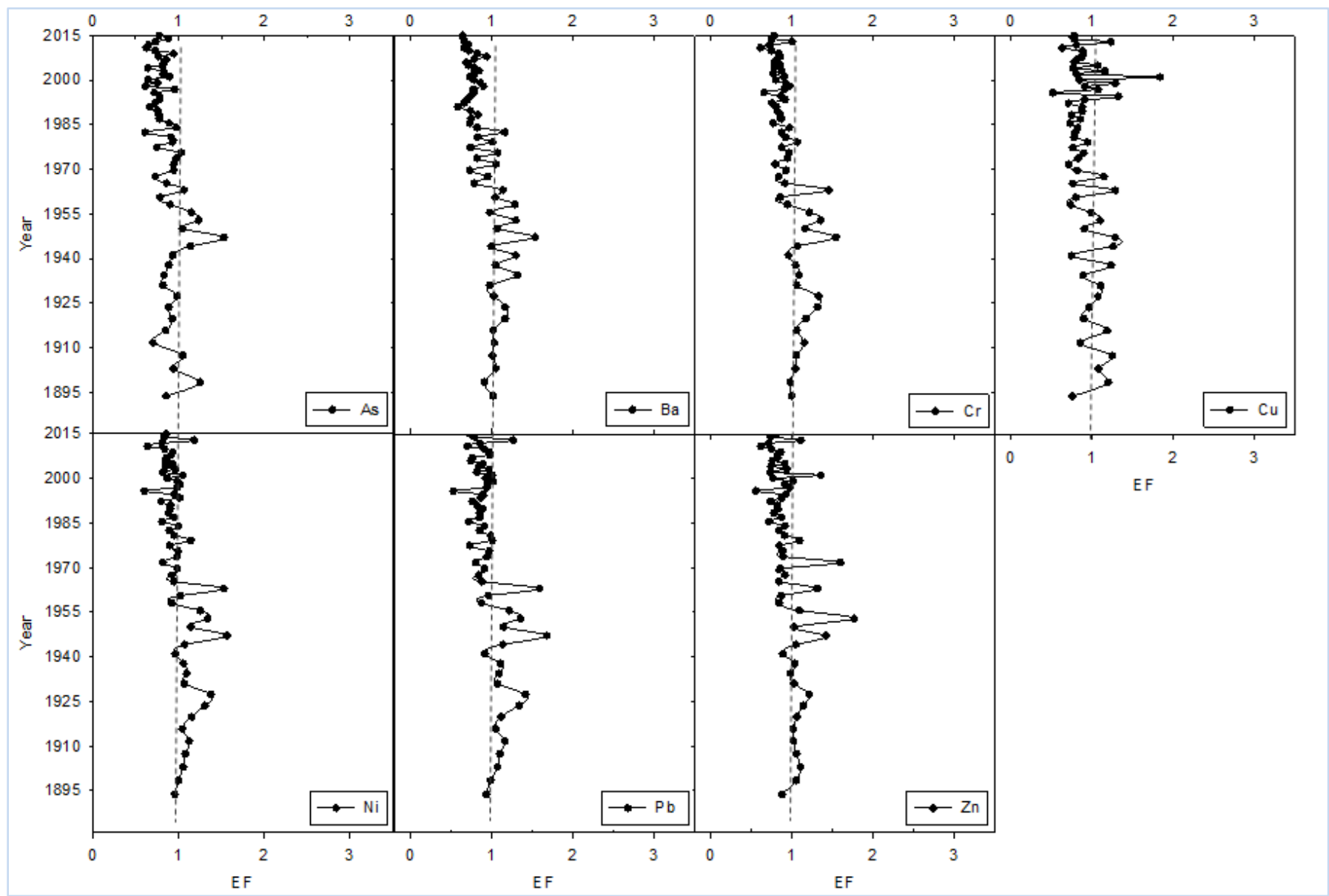

Fig. 3. Enrichment factor calculated for elements: $\mathrm{As}, \mathrm{Ba}, \mathrm{Cr}, \mathrm{Cu}, \mathrm{Ni}, \mathrm{Pb}$, and $\mathrm{Zn}$ for sediment core PT7.

\subsubsection{Geoaccumulation Index (Igeo)}

According to the Igeo classification (Müller, 1986), PT7 sediments were classified as unpolluted, as all elements presented Igeo results either below 0 or slightly higher. PT4 presented natural and unpolluted sediments for $\mathrm{Cr}, \mathrm{Cu}, \mathrm{Ni}$, $\mathrm{Pb}$ and $\mathrm{Zn}$. However, for $\mathrm{As}$ and $\mathrm{Ba}$, Igeo values were higher than 0 in the top $4 \mathrm{~cm}$, with values ranging from 0.13 to 0.41 . G4 showed values above 0 from 1989. In this sense, As presented increased values from approximately 1989 and Ba and $\mathrm{Zn}$ near 1993. From around 2000 to the most recent sediments, all analysed elements presented Igeo values higher than 0. Minimum and maximum Igeo results for all cores are shown in Tab. 6.

\subsubsection{Sediment Pollution Index (SPI)}

Overall, the three sediment cores exhibited either natural or non-contaminated sediments, with SPI values $<2$. Despite this, the observed trend is different in all the analysed cores (Fig. 6). In this sense, PT7 presented the highest values between the 1940s and the 1960s. However, in PT4 and G4 


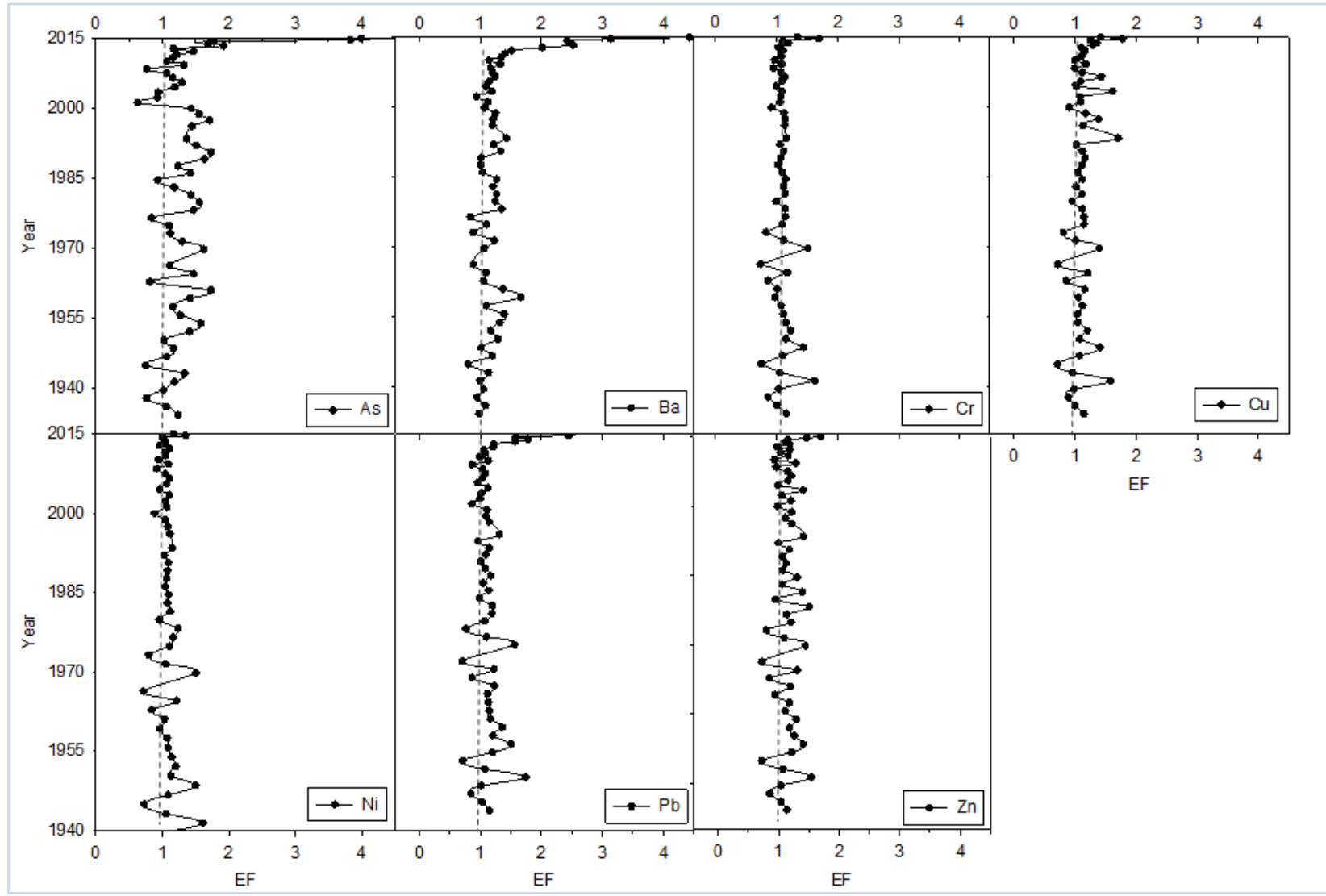

Fig. 4. Enrichment factor calculated for elements: $\mathrm{As}, \mathrm{Ba}, \mathrm{Cr}, \mathrm{Cu}, \mathrm{Ni}, \mathrm{Pb}$, and $\mathrm{Zn}$ in sediment core PT4.

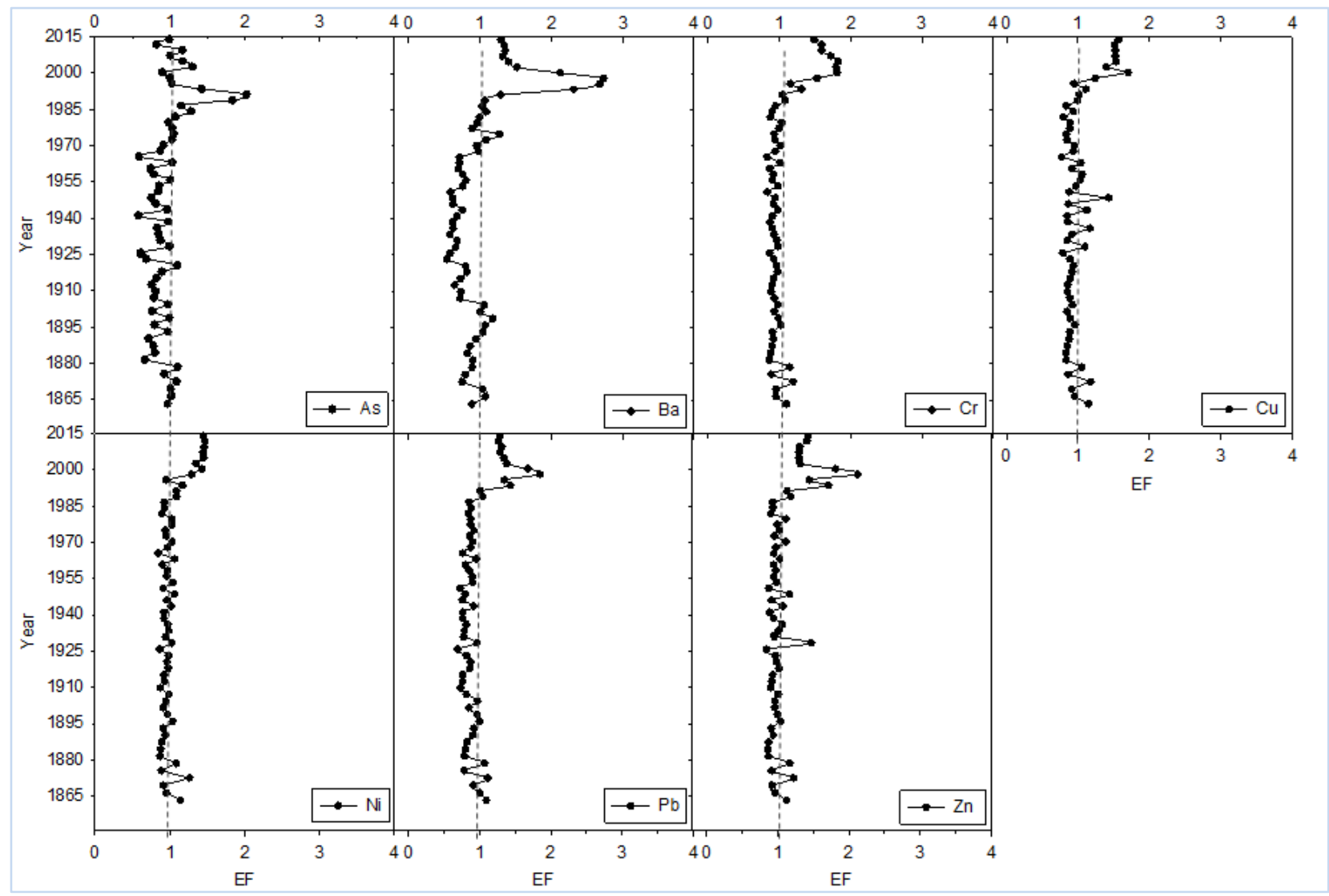

Fig. 5. Enrichment factor calculated for elements: $\mathrm{As}, \mathrm{Ba}, \mathrm{Cr}, \mathrm{Cu}, \mathrm{Ni}, \mathrm{Pb}$, and $\mathrm{Zn}$ in sediment core G4. 
highest values are found in the last decades. In PT4, there is an increasing trend after 2009, to values near 2 in the uppermost strata. In G4, constant values (near 1) are observed until approximately 1985 . Then, values increased until 2000, finally decreasing to constant values but still higher than baseline's conditions (Fig. 6).

\subsection{Organic matter composition}

Regarding $\delta^{13} \mathrm{C}$ values (Fig. 7A) for the three analysed cores, PT7 core presented constant values from the base until approximately $1940(-20.45 \pm 0.11 \%$ o). Then, a slight change is observed in the trend, with values ranging from $22.16 \%$ and $-20.24 \%$. PT4 showed constant values from the base until approximately $1975(-21.15 \pm 0.17 \% 0)$. After 1975 , values became more variable ranging between -22.54 $\% 0$ and $-20.63 \%$. In G4, between 1863 and 1931 values displayed an average of $-20.08 \pm 0.33 \%$. After that, a variable trend was observed with decreasing values up to 1958, then increasing up to 1975 and finally decreasing again reaching its minimum at the top stratum $(-24.85 \%$ o).

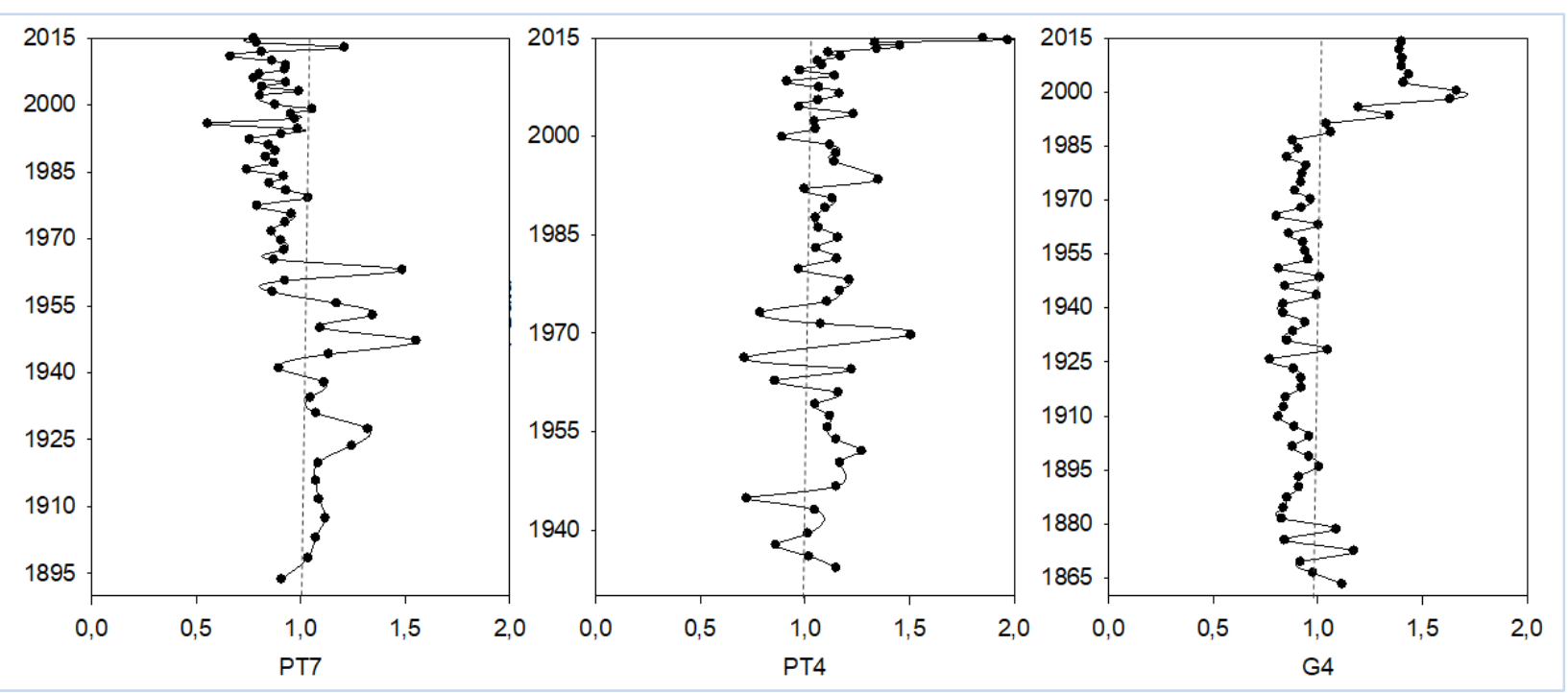

Fig. 6. SPI values for the three analysed sediment cores.

Tab. 6. Minimum and maximum Igeo values calculated for PT7, PT4 and G4 sediment cores.

\begin{tabular}{|l|c|c|c|c|c|c|}
\hline Cores & \multicolumn{2}{|c}{ PT7 } & \multicolumn{2}{c|}{ PT4 } & \multicolumn{2}{c|}{ G4 } \\
\hline Elem. & Min & Max & Min & Max & Min & Max \\
\hline As & -1.10 & -0.07 & -1.53 & $\mathbf{0 . 4 1}$ & -0.99 & $\mathbf{0 . 5 9}$ \\
\hline $\mathrm{Ba}$ & -1.15 & $\mathbf{0 . 2 0}$ & -1.20 & $\mathbf{0 . 3 7}$ & -1.35 & $\mathbf{0 . 7 9}$ \\
\hline $\mathrm{Cr}$ & -0.87 & -0.25 & -1.35 & -0.46 & -0.79 & $\mathbf{0 . 8 0}$ \\
\hline $\mathrm{Cu}$ & -0.95 & $\mathbf{0 . 1 7}$ & -1.27 & -0.36 & -0.80 & $\mathbf{0 . 6 6}$ \\
\hline $\mathrm{Ni}$ & -0.76 & -0.16 & -1.56 & -0.46 & -0.72 & $\mathbf{0 . 6 2}$ \\
\hline $\mathrm{Pb}$ & -0.90 & -0.16 & -1.02 & -0.23 & -0.81 & $\mathbf{0 . 4 0}$ \\
\hline $\mathrm{Zn}$ & -0.75 & 0.06 & -1.14 & -0.43 & -0.68 & $\mathbf{0 . 5 6}$ \\
\hline
\end{tabular}

\subsubsection{Pollution Load Index (PLI)}

PT7 and PT4 presented values close to 1, which correspond to baseline levels (Tab. 7). However, G4 presented a progressive deterioration of estuarine quality with values always higher than 1 from approximately 1980, and above 2 from approximately 2000.

For total organic carbon (TOC) (Fig. 7B), PT7 presented constant values along the core $(1.43 \pm 0.08 \%)$. Until approximately 2010, PT4 also showed similar values throughout the core $(1.51 \pm 0.11 \%)$ but with evident small peaks by mid 1970s $(1.76 \%)$, and by the end of the 1980 s
$(1.80 \%)$, and thereafter decreasing values reaching the minimum at the top stratum $(0.72 \%)$. In G4, total organic carbon values were variable and without a clear trend. In this sense, by the end of the $19^{\text {th }}$ century, values were close to 1 with an average of $1.1 \pm 0.09$. During the $20^{\text {th }}$ century TOC ranged from 0.61 to 2.11 , increasing constantly after 2000, and reaching the maximum in the top stratum $(2.53 \%)$.

Organic matter source for the three sites was inferred by using a modified model of the $\delta^{13} \mathrm{C}$ vs. C/N plot sensu Lamb et al., (2006) (Fig. 8). PT7 and PT4 presented similar organic matter sources associated with phytoplankton and C3 terrestrial plants. G4 presented a similar pattern until approximately 1984. Then, the signature of the organic matter changed, showing increased freshwater and terrestrial influence (Fig. 8).

Tab. 7. Minimum and maximum PLI values calculated for PT7, PT4 and G4 sediment cores.

\begin{tabular}{|c|c|c|c|}
\hline PLI & PT7 & PT4 & G4 \\
\hline Min & 0.87 & 0.80 & 0.89 \\
\hline Max & 1.33 & 1.09 & 2.09 \\
\hline
\end{tabular}

Correlations for all the analysed organic and inorganic variables in PT7, PT4 and G4 are shown in Tables 7, 8 and 
9 respectively. In PT7, significant correlations were observed between $\mathrm{Cr}, \mathrm{Ni}, \mathrm{Pb}$ and $\mathrm{Zn}$. No correlation was observed between metal concentration and organic matter proxies (Tab. 8). In PT4, $\mathrm{Cr}$ and $\mathrm{Ni}$ presented the strongest correlation. A positive correlation was also observed with $\mathrm{Zn}$. TOC correlated only with $\mathrm{Zn}$ and to a lesser extent with
$\mathrm{Ni}$ and $\mathrm{Cu}$. Sc, element associated with fine-grained sediment was positive correlated with $\mathrm{Cr}$ and $\mathrm{Ni}$ (Tab. 9).

In $\mathrm{G} 4$ there was a positive strong correlation between $\mathrm{Cr}$, $\mathrm{Cu}, \mathrm{Ni}, \mathrm{Sc}, \mathrm{Pb}$ and $\mathrm{Zn}$. TOC correlated with $\mathrm{As}$ and $\mathrm{Cr}$ $(>0.5), \mathrm{Cu}$ and $\mathrm{Ni}(>0.7)$ (Tab. 10).
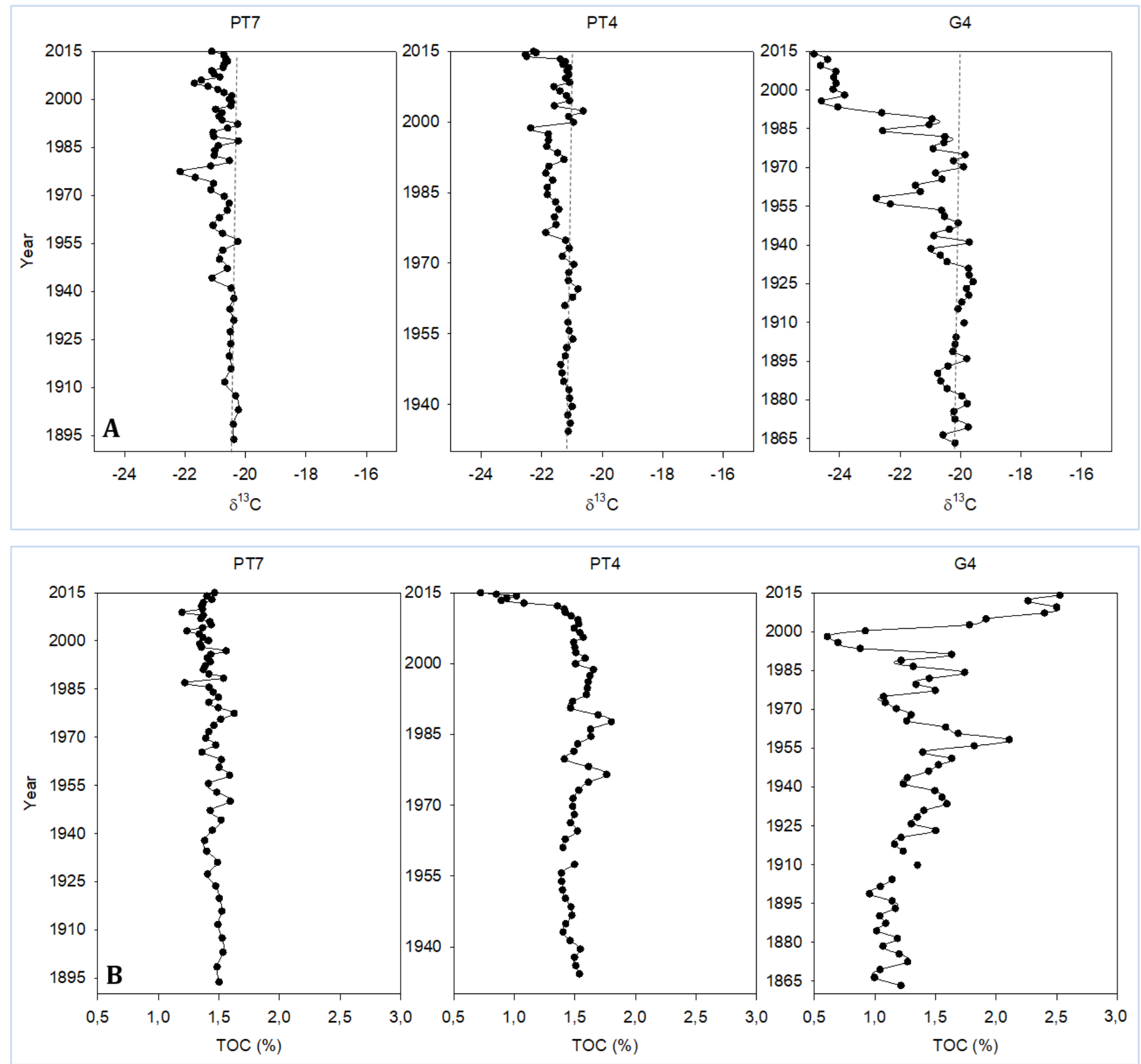

Fig. 7. A) $\delta^{13} \mathrm{C}$ values along the analysed sediment cores. Dotted lines show bottommost strata average values. B) Total organic carbon (TOC) (\%) along PT7, PT4 and G4.

\section{Discussion}

Sedimentation rates found in this study are consistent with values observed by Toldo Jr. et al. (2000) in the area. In this study, sedimentation rates were calculated based on ${ }^{210} \mathrm{~Pb}$ and ${ }^{14} \mathrm{C}$, finding that Holocene sedimentation in the lagoon ranged between 0.35 and $0.83 \mathrm{~cm} \mathrm{yr}^{-1}$. Furthermore, these values are higher than the sedimentation rates calculated for the last 8000 years BP based on ${ }^{14} \mathrm{C}$ dates $(0.05$ to $\left.0.08 \mathrm{~cm} \mathrm{yr}^{-1}\right)$.

These authors considered that higher ${ }^{210} \mathrm{~Pb}$ rates were associated with a more rapid sedimentation in the lagoon related to relatively recent deforestation of the watershed. 
Furthermore, Santos et al. (2008) who reviewed several studies about sedimentation rates in different Brazilian coastal environments, observed that the sedimentation rates calculated with ${ }^{14} \mathrm{C}$ were often lower than $1 \mathrm{~mm} / \mathrm{yr}$ and higher than $1 \mathrm{~mm} / \mathrm{yr}$ when obtained with $210 \mathrm{~Pb}$ measurements, suggesting an anthropogenic-driven change in the sedimentation process, even considering the effect of compaction on lower layers of the sedimentary column

Considering the different indices used to evaluate anthropogenic impact, those that integrate several elements (PLI and SPI) and those that evaluate the impact of a specific element (Igeo, EF), provided complementary results and interpretations.
RESEARCH PAPER

In this sense, Igeo and EF results indicated the specific elements that contributed to the changes in PLI and SPI trends. Furthermore, SPI and PLI results showed similar classifications for each core, indicating that both indices are suitable for showing general pollution trends in the area.

In PT7, located in a region near Camaquã River mouth, SPI and PLI indices suggested either natural or noncontaminated sediments. Furthermore, the lack of correlation between trace elements (especially $\mathrm{Ni}$ and $\mathrm{Cu}$ ) and TOC suggests not only oxic-dysoxic conditions but also that trace elements are mainly supplied by the detrital input (Algeo and Maynard., 2004; Tribovillard et al., 2006).

Tab. 8. Pearson correlation matrix for all the analysed variables in PT7.

\begin{tabular}{|l|c|c|c|c|c|c|c|c|c|c|c|}
\hline PT7 & $\mathrm{As}$ & $\mathrm{Ba}$ & $\mathrm{Cr}$ & $\mathrm{Cu}$ & $\mathrm{Ni}$ & $\mathrm{Pb}$ & $\mathrm{Sc}$ & $\mathrm{Zn}$ & $\%$ TOC & $\delta{ }^{13} \mathrm{C}$ & $\mathrm{C} / \mathrm{N}$ \\
\hline $\mathrm{As}$ & & $<0.01$ & $<0.01$ & 0.67 & $<0.01$ & 0.06 & 0.00 & $<0.01$ & 0.53 & 0.11 & 0.42 \\
\hline $\mathrm{Ba}$ & 0.39 & & $<0.01$ & 0.19 & 0.02 & 0.02 & 0.01 & 0.01 & 0.65 & 0.97 & 0.32 \\
\hline $\mathrm{Cr}$ & 0.47 & $\mathbf{0 . 6 2}$ & & 0.06 & $<0.01$ & $<0.01$ & 0.01 & $<0.01$ & 0.63 & 0.91 & 0.84 \\
\hline $\mathrm{Cu}$ & 0.06 & -0.17 & -0.24 & & 0.44 & 0.30 & 0.04 & $<0.01$ & 0.00 & 0.81 & 0.87 \\
\hline $\mathrm{Ni}$ & 0.42 & 0.29 & $\mathbf{0 . 8 1}$ & 0.10 & & $<0.01$ & 0.00 & $<0.01$ & 0.13 & 0.48 & 0.30 \\
\hline $\mathrm{Pb}$ & 0.24 & 0.31 & $\mathbf{0 . 6 4}$ & 0.14 & $\mathbf{0 . 7 7}$ & & 0.05 & $<0.01$ & 0.05 & 0.54 & 0.71 \\
\hline $\mathrm{Sc}$ & 0.51 & 0.35 & 0.35 & 0.26 & 0.52 & 0.25 & & 0.00 & 0.02 & 0.05 & 0.34 \\
\hline $\mathrm{Zn}$ & 0.43 & 0.33 & $\mathbf{0 . 5 3}$ & 0.40 & $\mathbf{0 . 6 5}$ & $\mathbf{0 . 5 4}$ & 0.38 & & 0.12 & 0.88 & 0.95 \\
\hline \% TOC & -0.08 & 0.06 & 0.06 & -0.37 & -0.20 & -0.25 & -0.31 & -0.20 & & 0.15 & 0.01 \\
\hline$\delta^{13} \mathrm{C}$ & -0.21 & 0.00 & 0.01 & 0.03 & -0.09 & 0.08 & -0.26 & -0.02 & -0.19 & & 0.67 \\
\hline $\mathrm{C} / \mathrm{N}$ & -0.11 & 0.13 & -0.03 & 0.02 & -0.14 & -0.05 & -0.13 & -0.01 & 0.35 & -0.06 & \\
\hline
\end{tabular}

Tab. 9. Pearson correlation matrix for all the analysed variables in PT4.

\begin{tabular}{|l|c|c|c|c|c|c|c|c|c|c|c|}
\hline $\mathrm{PT} 4$ & $\mathrm{As}$ & $\mathrm{Ba}$ & $\mathrm{Cr}$ & $\mathrm{Cu}$ & $\mathrm{Ni}$ & $\mathrm{Pb}$ & $\mathrm{Sc}$ & $\mathrm{Zn}$ & $\%$ TOC & $\delta^{13} \mathrm{C}$ & $\mathrm{C} / \mathrm{N}$ \\
\hline $\mathrm{As}$ & & $<0.01$ & 0.90 & 0.18 & 0.30 & 0.01 & 0.63 & 0.13 & 0.01 & 0.05 & 0.16 \\
\hline $\mathrm{Ba}$ & 0.49 & & $<0.01$ & 0.01 & $<0.01$ & 0.09 & 0.68 & $<0.01$ & $<0.01$ & 0.04 & $<0.01$ \\
\hline $\mathrm{Cr}$ & -0.02 & -0.40 & & $<0.01$ & $<0.01$ & $<0.01$ & 0.00 & $<0.01$ & 0.01 & 0.00 & 0.33 \\
\hline $\mathrm{Cu}$ & -0.18 & -0.36 & $\mathbf{0 . 5 3}$ & & $<0.01$ & 0.38 & 0.01 & $<0.01$ & $<0.01$ & 0.22 & 0.23 \\
\hline $\mathrm{Ni}$ & -0.14 & -0.54 & $\mathbf{0 . 9 5}$ & $\mathbf{0 . 5 3}$ & & 0.02 & 0.00 & $<0.01$ & $<0.01$ & 0.00 & 0.08 \\
\hline $\mathrm{Pb}$ & 0.34 & 0.23 & 0.41 & 0.12 & 0.30 & & 0.50 & 0.57 & $<0.01$ & 0.69 & $<0.01$ \\
\hline $\mathrm{Sc}$ & -0.06 & -0.06 & $\mathbf{0 . 6 0}$ & 0.35 & $\mathbf{0 . 5 8}$ & -0.09 & & 0.00 & 0.01 & 0.00 & 0.05 \\
\hline $\mathrm{Zn}$ & -0.20 & -0.45 & $\mathbf{0 . 6 1}$ & 0.42 & $\mathbf{0 . 7 3}$ & 0.08 & 0.38 & & $<0.01$ & 0.01 & 0.05 \\
\hline$\% \mathrm{TOC}$ & -0.32 & -0.67 & 0.36 & 0.44 & 0.48 & -0.37 & 0.35 & $\mathbf{0 . 5 4}$ & & 0.60 & $<0.01$ \\
\hline$\delta^{13} \mathrm{C}$ & -0.26 & -0.27 & 0.42 & 0.16 & 0.48 & -0.05 & 0.45 & 0.36 & 0.07 & & 0.93 \\
\hline $\mathrm{C} / \mathrm{N}$ & -0.19 & -0.56 & 0.13 & 0.16 & 0.23 & -0.49 & 0.26 & 0.26 & 0.63 & 0.01 & \\
\hline
\end{tabular}

In core PT7, total organic carbon also displayed a constant trend, and no significant variations were observed. Overall, this region does not seem to be affected by the mining activities upstream Camaquã River. The prevailing wind forced circulation in Patos Lagoon is characterised by the presence of several cells with downwind velocity near the margins and upwind return flow occurring in the central areas (Moller et al., 1996; Fernandes et al., 2002). In this sense, the downwind circulation near the margins would contribute to dissipate the pollution coming from the river. Furthermore, contaminants would be deposited upstream in central areas by the upwind return flow.

In core PT4, located between Camaquã River mouth and Guaíba River, SPI and PLI indices indicated no significant anthropogenic impact, even though this core presented a slight increase in the uppermost strata, but environmental quality still lies within unpolluted ranges. However, according to the EF and Igeo, after 2009 most of the 
elements showed a steady increase. Especially, As, $\mathrm{Ba}$ and $\mathrm{Pb}$ showed moderately polluted levels. Such elements did not exhibit correlation between each other, thus probably indicating different sources of contamination.

In this sense, barite $\left(\mathrm{BaSO}_{4}\right)$ is a sulphide-mineral exploited upstream Camaquã River, and despite the great dilution potential of the lagoon, this activity influences the sedimentary composition. Another contribution of Ba could be coal mining, since this is also an important activity in the region that significantly contributes to the contamination of the lagoon (Baisch and Wasserman,1998) and this element is found in coal at high concentrations (Choudhury and Cary, 2001). Regarding As high concentrations, the source of this element in PT7 site is probably Camaquã River, since it is located in a region influenced by both impacted streams (Camaquã and Guaíba), but the core near Guaíba (G4) did not show As enrichment. In this sense, Mirlean et al. (2003) studied As concentration in surficial sediments of Patos Lagoon and found maximum concentrations of this element downstream of Camaquã River with concentrations increasing about five times more than baseline after the river discharge into the lagoon, suggesting an origin associated with the redeposition of arsenate minerals from tailings of sulphide ore deposits located in the Camaquã River drainage basin. In the case of $\mathrm{Pb}$, Baisch and Wasserman (1998) suggested that the anthropogenic enrichment of this element might be the result of a combination of both Camaquã and Guaíba rivers. The positive correlation between $\mathrm{Cr}, \mathrm{Ni}, \mathrm{Cu}$ and $\mathrm{Zn}$ as well as their low EF suggests the absence of contamination for these elements in this region.
As expected, highest concentrations and indices values were detected in the northern part of the system. In this sense, sediment core G4 did present signs of contamination. SPI and PLI indices showed a progressive deterioration of the lagoon quality after 1980 reaching poorest environmental conditions around 2000. At that time, Igeo and EF maximum values were observed reaching levels of moderate pollution for all analysed elements.

Despite the distance from Porto Alegre City, the region where core G4 was collected is dominated by depositional processes (Nicolodi et al., 2010), and according to the hydrodynamic model from Paz et al. (2005), the untreated waters carrying contaminants from Porto Alegre City and adjacent locations (Dias Prestes and Quadros Rückert, 2017) can certainly reach the region were G4 was collected.

It is well known that Guaíba River is a source of high contamination and untreated domestic and industrial sewage (Dias Prestes and Quadros Rückert, 2017). However, the EF values only showed moderate pollution levels suggesting a considerable dilution process within the system. This was also observed by Baisch and Wasserman (1998) who attributed such low levels to the mixture with the metaldepleted lagoon sediments and the dissolution of metals associated with oxihydroxides and organic matter under reducing conditions of the sediments. This could also be supported by our results as high correlation between TOC and trace elements would indicate reducing sediment conditions (Algeo and Maynard, 2004; Tribovillard et al., 2006).

Tab. 10. Pearson correlation matrix for all the analysed variables in G4.

\begin{tabular}{|l|c|c|c|c|c|c|c|c|c|c|c|}
\hline $\mathrm{G} 4$ & $\mathrm{As}$ & $\mathrm{Ba}$ & $\mathrm{Cr}$ & $\mathrm{Cu}$ & $\mathrm{Ni}$ & $\mathrm{Pb}$ & $\mathrm{Sc}$ & $\mathrm{Zn}$ & \% TOC & $\delta^{13} \mathrm{C}$ & $\mathrm{C} / \mathrm{N}$ \\
\hline $\mathrm{As}$ & & $<0.01$ & $<0.01$ & $<0.01$ & $<0.01$ & $<0.01$ & 0.00 & $<0.01$ & $<0.01$ & $<0.01$ & $<0.01$ \\
\hline $\mathrm{Ba}$ & 0.39 & & $<0.01$ & 0.83 & 0.05 & $<0.01$ & 0.34 & 0.00 & 0.93 & $<0.01$ & 0.90 \\
\hline $\mathrm{Cr}$ & $\mathbf{0 . 5 2}$ & $\mathbf{0 . 5 1}$ & & $<0.01$ & $<0.01$ & $<0.01$ & 0.00 & $<0.01$ & $<0.01$ & $<0.01$ & $<0.01$ \\
\hline $\mathrm{Cu}$ & 0.38 & 0.03 & $\mathbf{0 . 6 8}$ & & $<0.01$ & $<0.01$ & 0.00 & $<0.01$ & $<0.01$ & $<0.01$ & $<0.01$ \\
\hline $\mathrm{Ni}$ & $\mathbf{0 . 5 2}$ & 0.26 & $\mathbf{0 . 9 2}$ & $\mathbf{0 . 8 1}$ & & $<0.01$ & 0.00 & $<0.01$ & $<0.01$ & $<0.01$ & $<0.01$ \\
\hline $\mathrm{Pb}$ & $\mathbf{0 . 5 3}$ & $\mathbf{0 . 7 4}$ & $\mathbf{0 . 8 6}$ & 0.49 & $\mathbf{0 . 6 9}$ & & 0.00 & $<0.01$ & 0.01 & $<0.01$ & 0.03 \\
\hline $\mathrm{Sc}$ & 0.44 & 0.13 & $\mathbf{0 . 7 0}$ & $\mathbf{0 . 6 0}$ & $\mathbf{0 . 8 1}$ & 0.43 & & 0.00 & 0.00 & 0.26 & 0.00 \\
\hline $\mathrm{Zn}$ & 0.42 & 0.41 & $\mathbf{0 . 8 3}$ & $\mathbf{0 . 7 7}$ & $\mathbf{0 . 7 6}$ & $\mathbf{0 . 7 6}$ & 0.50 & & $<0.01$ & 0.00 & $<0.01$ \\
\hline$\% \mathrm{TOC}$ & $\mathbf{0 . 5 5}$ & -0.01 & $\mathbf{0 . 5 6}$ & $\mathbf{0 . 7 9}$ & $\mathbf{0 . 7 8}$ & 0.36 & $\mathbf{0 . 7 3}$ & 0.48 & & 0.02 & $<0.01$ \\
\hline$\delta^{13} \mathrm{C}$ & -0.43 & -0.71 & -0.58 & -0.43 & -0.43 & -0.78 & -0.15 & -0.65 & -0.31 & & 0.02 \\
\hline $\mathrm{C} / \mathrm{N}$ & 0.45 & 0.02 & 0.37 & 0.48 & 0.49 & 0.29 & 0.46 & 0.42 & 0.61 & -0.31 & \\
\hline
\end{tabular}

Regarding the organic matter composition, in PT7 $\delta^{13} \mathrm{C}$ signature as well as $\mathrm{C} / \mathrm{N}$ ratio and TOC (\%) indicate constant organic sources up to 1940 . After this period only little variation in composition was inferred lying always within the same ranges indicating possible minor or diluted local inputs of domestic and industrial activities from Río Grande or Camaquã region.
Cyanobacterial blooms might also have contributed to this change as depleted $\delta^{13} \mathrm{C}$ values suggests that bacterially assimilated carbon contributed to the sedimentary carbon budget (Teranes and Bernasconi, 2005).

In this sense, Microcystis aeruginosa blooms were recorded in Patos Lagoon since the 1980s (Yunes et al., 1998; de Souza et al., 2018), but previous observations of locals date back to 
the beginning of the 20th century. Anyway, the system displays still fairly undisturbed conditions, thus highlighting the highly dynamic dilution potential of the lagoon.

In PT4 core, the values were quite constant from the base until approximately the last decade, from which the values decreased, presenting however a few peaks. Assuming pristine conditions, such observed peaks might be a consequence of natural variability of the system. This sediment core displayed fairly good sedimentation conditions, presenting the highest sedimentation rate with an average $0.55 \pm 0.01 \mathrm{~cm} \mathrm{yr}^{-1}$ and some values of $\approx 1 \mathrm{~cm} \mathrm{yr}^{-1}$. Therefore, it might be appropriate to integrate and infer climatic variability processes attributable to El Niño events. In southern Brazil, El Niño phase is characterised by increased precipitation (Fernandes et al., 2002). In accordance with this, the National Oceanic and Atmospheric Administration (NOAA) registered strong El Niño phases in 1972-1973, 1982-1983 and 1987-1988.

In this sense, the variability observed in the organic carbon content by mid 1970s and by the end of the 1980s might be a consequence of such intense precipitation and increased runoff registered in the area. Furthermore, the maximum total annual precipitation registered for Porto Alegre City by INMET (National Meteorology Institute of Brazil) between 1961 and 2015 corresponded to 1972 with $1983.6 \mathrm{~mm}$. On the other hand, the observed decreasing
RESEARCH PAPER

trend in total organic carbon during the last decade might be related to the deforestation already observed in the area (Toldo Jr et al., 2000; Niencheski et al., 2004b). In this sense, Pérez et al., (2017) associated a reduction in the TOC sequestration with vegetation removal due to anthropogenic deforestation.

Core G4 displayed a completely different trend, as it is clearly influenced by Porto Alegre City so organic matter composition is a combined response of natural variability and anthropogenic impact. In this region, organic impact was already observed by the beginning of the 19th century, with the use of streets and vacant land for the dumping of garbage (Dias Prestes and Quadros Rückert, 2017).

As Core G4 recorded about 150 years while organic impact began at about 200 years ago, further investigation might be needed in order to assess organic matter background levels and sources for this region. In addition, despite the variability observed from 1860s until the present, TOC is currently two times higher, and the recent organic matter is depleted in $\delta^{13} \mathrm{C}$ indicating a shift in the organic matter composition (Meyers, 2003; Lamb et al., 2006). Bacterially assimilated carbon, depleted in $\delta{ }^{13} \mathrm{C}$, might also have contributed to the decrease of the $\delta^{13} \mathrm{C}$ sedimentary values, once cyanobacterial blooms were recorded since the 1970s in Guaíba (Ribeiro et al., 2012).

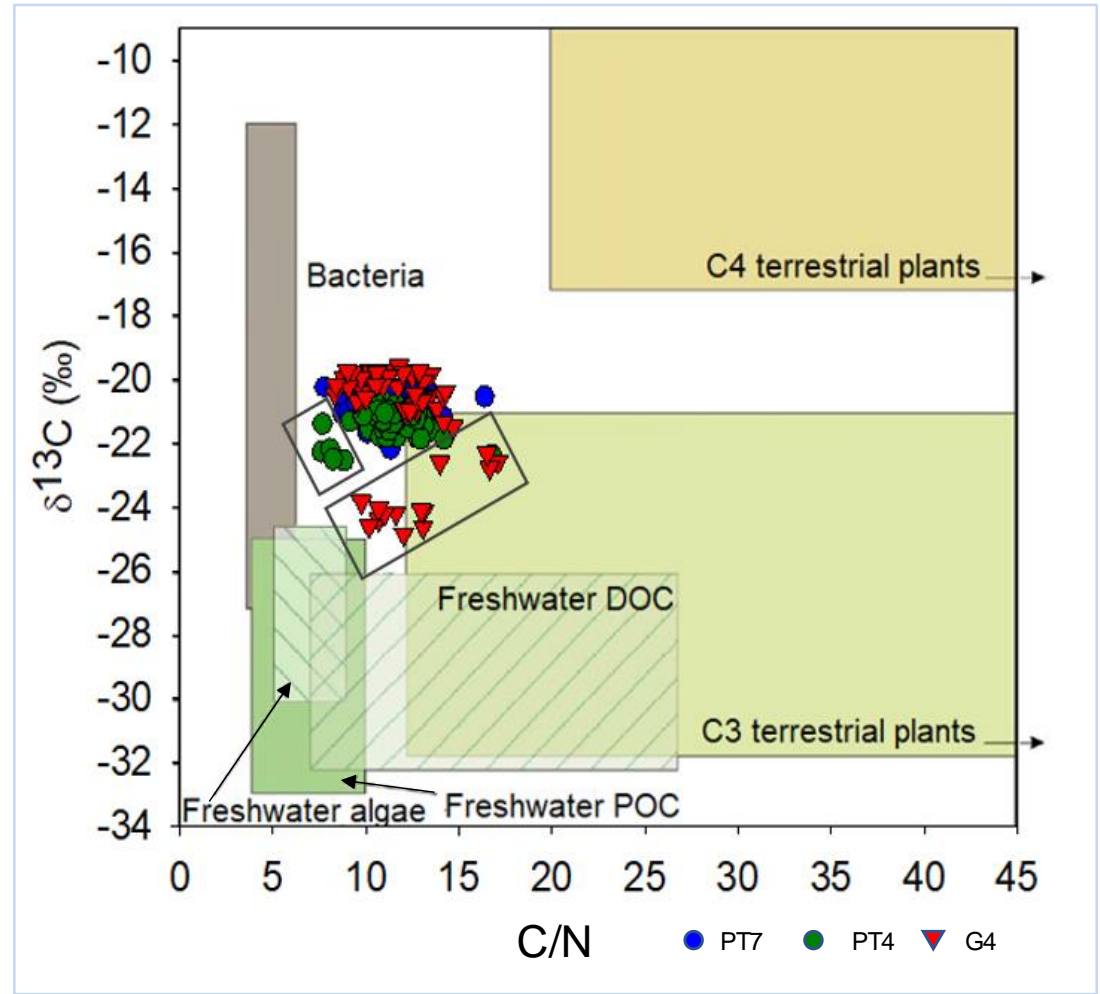

Fig. 8. $\delta^{13} \mathrm{C}$ vs. $\mathrm{C} / \mathrm{N}$ values for the three analysed cores incorporated to the modified Lamb et al., (2006) plot. Boxes contain most recent records for PT7 (circles) and G4 (triangles). 
In Patos Lagoon, the main source of organic matter is supplied by the Guaíba River (Baisch and Wasserman, 1998), which explains the similar isotopic signature in the whole lagoon prior to the anthropogenic influence. The isotopic signature changed differentially after the anthropogenic fingerprint in the analysed sedimentary records. In this sense, recent sediments of PT4 core evidenced a shift in the vegetal cover, while the G4 site was influenced by both urban and industrial activities of Porto Alegre City.

This is the first isotopic analysis of ancient sediments in the freshwater zone of Patos Lagoon. The closest similar study was undertaken by Patterson (2016), who studied stocks and sources of carbon in the saltmarshes of the estuarine region of this lagoon. However, despite the proximity of the study areas, the isotopic signature is not comparable to the results obtained by Patterson (2016). This author observed that the sedimentary carbon in the marshes are related to the local estuarine vegetation. This suggests that the most significant source of carbon in marshes comes from your own natural productivity.

Regionally, similar studies were performed in other Brazilian coastal lagoons and estuaries such as Guanabara Bay (Baptista Neto et al., 2013), Baixada Santista region (Luiz-Silva et al., 2008; Silva et al., 2011) and Carapebus Lagoon (Soares et al., 2019) obtaining comparable results. In Guanabara Bay, located in Río de Janeiro and surrounded by the second largest city of the country, the increased river discharges and sediment loads flowing into the bay as a consequence of the anthropogenic activities, caused an increment in the sedimentation rate. Also, metals such as $\mathrm{Cu}$, $\mathrm{Cr}, \mathrm{Ni}, \mathrm{Pb}$ and $\mathrm{Zn}$ showed a constant increased over the last five decades, with the highest concentrations in the top layers because of untreated sewage dumping into the bay as well as industrial activities (Baptista Neto et al., 2013).

In the Baixada Santista area, the elements that best reflected the anthropogenic impact were $\mathrm{Cr}, \mathrm{Zn}$ and $\mathrm{Fe}$ (Luiz-Silva et al., 2008; Silva et al., 2011. In the case of Fe, even though it is a conservative element often used as a normalising element (Birch, 2003), in this specific area this element also has an anthropogenic contribution from the steel industry. Therefore, it is a reliable indicator of contamination instead of lithogenic input (Luiz-Silva et al., 2008). In Carapebus Lagoon, a transition period was observed in the sedimentary record, where the pre- and postanthropic influence was clearly evidenced. In this sense, the most recent sedimentary unit was characterised as a high organic and metal content zone (specially $\mathrm{Cd}, \mathrm{Cr}, \mathrm{Cu}, \mathrm{Pb}$ and Zn) (Soares et al., 2019).

Regarding the organic input, in Carapebus Lagoon total organic carbon content increased by twice in the most recent sediment when compared to pre-anthropogenic values. Furthermore, the $\mathrm{C} / \mathrm{N}$ ratio changed indicating a shift in the organic matter source, from terrestrial to autochthonous associated with a sustained input of untreated effluents (Soares et al., 2019). The same pattern was observed in
Guanabara Bay, where the organic carbon flux increased by about twice since the beginning of the last century, also associated with untreated sewage (Baptista Neto et al., 2013).

\section{Conclusion}

The advantage of using several metal indices is reflected in this work, where all indices presented complementing information that helped us to provide an accurate evaluation of the metal input in Patos Lagoon along time.

Multiple-element indices SPI and PLI both showed a general overview of the environmental conditions of the lagoon along time. Furthermore, single-element indices explained which elements triggered the observed changes in the environmental trends.

Although the increase in the concentration of contaminants can be observed in recent decades, and the anthropic impact on the region is well documented, the central region of the lagoon has almost undisturbed conditions, probably due to the high dilution potential of the lagoon. In this sense, the influence of Camaquã River basin activities is observed mainly upstream, probably as a consequence of the hydrodynamics of the lagoon.

Long-term anthropogenic influence in the lagoon was also revealed by a differentially change in the isotopic composition of the organic matter. Overall, metals together with organic matter composition proxies allowed to determine the anthropic-related changes in Patos Lagoon.

\section{Acknowledgments}

The authors would like to thank ANII (POS_NAC_2017_1_141233) and CSIC MIA 118 for the financial support. Also, LaQIMar members for the kind support during the stay. Universidade Federal do Rio Grande do Sul (UFRGS), is also thanked for the logistic support during the sampling campaign.

\section{References}

Algeo, T.J., Maynard, J.B., 2004. Trace-element behavior and redox facies in core shales of Upper Pennsylvanian Kansastype cyclothems. Chemical Geology 206, 289- 318. https://doi.org/10.1016/j.chemgeo.2003.12.009

Appleby, P.G., Oldfield, F., 1983. The assessment of $210 \mathrm{~Pb}$ data from sites with varying sediment accumulation rates. Hydrobiologia 103, 29-35. https://doi.org/10.1007/BF00028424

Baisch, P.R., Wasserman, J.R., 1998. Chemistry and distribution of trace elements in the Patos lagoon, South Brazil. In: Wasserman, J.C., Silva-Filho, E.V., Villas-Boas, R. (Eds), Environmental Geochemistry in the Tropics. Lecture Notes in Earth Sciences, vol 72. Springer, Berlin, Heidelberg, pp. 97126. https://doi.org/10.1007/BFb0010908

Baptista Neto, J.A., Peixoto, T.C.S., Smith, B.J., Mcalister, J.J., Patchineelam, S.M., Patchineelam, S.R., Fonseca, E.M., 2013. Geochronology and heavy metal flux to Guanabara Bay, Rio de Janeiro state: a preliminary study. Anais da Academia Brasileira de Ciências 85, 1317-1327. http://dx.doi.org/10.1590/0001-3765201394612 
Birch, G., 2013. Use of Sedimentary-metal indicators in assessment of estuarine system. In: Shroder, Jr, J. (Editor in Chief), Switzer, A., Kennedy, D., Treatise on Geomorphology. Academic Press, San Diego, vol. 14. https://doi.org/10.1016/B978-012-374739-6.00392-4

Birch, G.F., 2017. Determination of sediment metal background concentrations and enrichment in marine environments - A critical review. Science of the Total Environment 580, 813831. https://doi.org/10.1016/j.scitotenv.2016.12.028

Birch, G.F., Olmos, M., 2008. Sediment-bound heavy metals as indicators of human influence and biological risk in coastal water bodies. Journal of Marine Science 65, 1407-1413. https://doi.org/10.1093/icesjms/fsn139

Birch, G.F., 2007. A short geological and environmental history of the Sydney estuary, Australia. 217-246. In: Birch, G.F. (Ed.), Water, Wind, Art and Debate. Sydney University Press, The Sydney University, Australia, 433 pp.

Birch, G.F., 2003. A test of normalization methods for marine sediment, including a new post-extraction normalization (PEN) technique. Hydrobiologia 492, 5-13. https://doi.org/10.1023/A:1024844629087

Calliari, L.J., Winterwerp, J.C., Fernandes, E., Cuchiara, D., Vinzon, S.B., Sperle, M., Holland, K.T., 2009. Fine grain sediment transport and deposition in the Patos LagoonCassino beach sedimentary system. Continental Shelf Research 29, 515-529. https://doi.org/10.1016/j.csr.2008.09.019

Ceni, G., Fontoura, N.F., Cabral, H.N, 2016. The freshwater artisanal fishery of Patos Lagoon. Journal of Fish Biology 89, 337-354. https://doi.org/10.1111/jfb.13004

Choudhury, H., Cary, R., 2001. Barium and Barium Compounds. Concise International Chemical Assessment Document 33. World Health Organization, Geneva. ISSN 1020-6167

Claudino, M.C., Abreu, P.C., Garcia, A.M., 2013. Stable isotopes reveal temporal and between-habitat changes in trophic pathways in a southwestern Atlantic estuary. Marine Ecology Progress Series 489, 29-42. https://doi.org/10.3354/meps10400

de Souza, M.S., Muelbert, J.H., Costa, L.D.F., Klering, E.V., Yunes, J.S., 2018. Environmental Variability and Cyanobacterial Blooms in a Subtropical Coastal Lagoon: Searching for a Sign of Climate Change Effects. Frontiers in Microbiology 9, 1727. https://doi.org/10.3389/fmicb.2018.01727

Dias Prestes, A.J., Quadros Rückert, F., 2017. A cidade de Porto Alegre e as águas do Guaíba: uma história de "encontros" e "desencontros". Cadernos de História, Belo Horizonte 18, 485510. https://doi.org/10.5752/P.2237-8871.2017v18n29p485

Fernandes, E.H.L., Dyera, K.R., Moller, O.O., Niencheski, L.F.H., 2002. The Patos Lagoon hydrodynamics during an El Niño event, 1998. Continental Shelf Research 22, 1699-1713. https://doi.org/10.1016/S0278-4343(02)00033-X

Ferreira P.A.L., Ribeiro, A.P., Nascimento M.G., Martins C.C., Mahiques M.M., Montone R.C., Figueira R.C.L., 2013. ${ }^{137} \mathrm{Cs}$ in marine sediments of Admiralty Bay, King George Island, Antarctica. Science of the Total Environment 443, 505-510. https://doi.org/10.1016/j.scitotenv.2012.11.032

Kjerfve, B., 1994. Coastal Lagoons. In: Kjerfve, B (eds). Coastal Lagoon Processes. Elsevier Oceanography Series 60, 1-8.

Kütter, V.T., Mirlean, N., Baisch, P.R.M, Kütter, M.T., Silva-Filho, E.V, 2008. Mercury in freshwater, estuarine, and marine fishes
RESEARCH PAPER

from Southern Brazil and its ecological implication. Environmental Monitoring and Assessment 159, 35-42. https://doi.org/10.1007/s10661-008-0610-1

Lamb, A.L., Wilson, G.P. Leng, M.J., 2006. A review of coastal palaeoclimate and relative sea-level reconstructions using $\delta^{13} \mathrm{C}$ and $\mathrm{C} / \mathrm{N}$ ratios in organic material. Earth- Science Reviews 75 , 29-57. https://doi.org/10.1016/j.earscirev.2005.10.003

Lima, A.C.R., Hoogmoed, W.B., Brussaard, L., Sacco dos Anjos, F., 2011. Farmers' assessment of soil quality in rice production systems. NJAS -Wageningen Journal of Life Sciences 58, $31-$ 38. https://doi.org/10.1016/j.njas.2010.08.002

Loring, D.H., Rantala, R.T.T., 1992. Manual for the geochemical analyses of marine sediments and suspended particulate matter. Earth Science Reviews 32, 238-282. https://doi.org/10.1016/0012-8252(92)90001-A

Loring, D.H., 1988. Normalization of heavy metal data. Report of the 75th Statutory Meeting of WGMS in Relation to Pollution, Annex 2. ICES Publications, Copenhagen, pp. 19-42.

Luiz-Silva, W., Machado, W., Matos, R.H.R., 2008. MultiElemental Contamination and Historic Record in Sediments from the Santos-Cubatão Estuarine System, Brazil. Journal of the Brazilian Chemical Society 19, 1490-1500. http://dx.doi.org/10.1590/S0103-50532008000800008

Meyers, P.A., 2003. Applications of organic geochemistry to paleolimnological reconstructions: a summary of examples from the Laurentian Great Lakes. Organic Geochemistry 34, 261-289. https://doi.org/10.1016/S0146-6380(02)00168-7

Meyers, P.A., 1994. Preservation of elemental and isotopic source identification of sedimentary organic matter. Chemical Geology 114, 289-302. https://doi.org/10.1016/00092541(94)90059-0

Mirlean, N., Andrus, V.E., Baisch, P., Griep, G., Casartelli, M.R., 2003. Arsenic pollution in Patos Lagoon estuarine sediments, Brazil. Marine Pollution Bulletin 46, 1480-1484. https://doi.org/10.1016/S0025-326X(03)00257-1

Moller Jr, O.O., Lorenzzentti, J.A., Stech, J.L., Mata, M.M, 1996. The Patos Lagoon summertime circulation and dynamics. Continental Shelf Research 16, 335-351. https://doi.org/10.1016/0278-4343(95)00014-R

Müller, V.G., 1986. Schadstoffe in Sedimenten - Sedimente als Schadstoffe. Mitteilungen der Österreichischen Geologischen Gesellschaft 79, 107-126.

Nicolodi, J.L., Toldo, E.E., Farina, L., 2010. Dinâmica e ressuspensão por ondas no Lago Guaíba (RS, Brasil) e implicações nos locais de captação de água para abastecimento humano. Pesquisas em Geociências 37, 25-39. https:/ / doi.org/10.22456/1807-9806.17726

Niencheski, L.F.H., Baraj, B., Windom, H.L., França, R.G., 2004a. Natural Background Assessment and Its Anthropogenic Contamination of $\mathrm{Cd}, \mathrm{Pb}, \mathrm{Cu}, \mathrm{Cr}, \mathrm{Zn}, \mathrm{Al}$ and $\mathrm{Fe}$ in the Sediments of the Southern Area of Patos Lagoon. Journal of Coastal Research 39, 1040-1043.

Niencheski, L.F.H., Zepka Baumgarten, M.G., Cabrera, L., Juliano, S.K., 2004b. Patos Lagoon: Indicators of Organic Pollution. Journal of Coastal Research 39, 1356-1359.

Odebrecht, C, Abreu, P.C., Bem-Venuti, C.E, Copertino, M., Muelbert, J.H., Vieira, J.P., Seeliger, U., 2010. The Patos Lagoon Estuary, Southern Brazil biotic responses to natural and anthropogenic impacts in the last decades (1979-2008). In: Kennish, M.J., Paerl H.W. (Eds.). Coastal Lagoons. Critical 
Habitats of Environmental Change, pp. 433-455. https://doi.org/10.1201/ebk1420088304-c17

Odebrecht, C., Abreu, P.C., Bem-Venuti, C.E., Colling, A.L., Copertino, M., Costa, C.S.B., Garcia, A.M., Marangoni, J.C., Moller Jr., O.O., Muelbert, J.H., Vieira, J.P., Seeliger, U., 2013. O Efeito de Perturbações Naturais e Antrópicas na Ecologia do Estuário da Lagoa dos Patos. In: Marcelo Tabarelli, Carlos Frederico Duarte da Rocha, Helena Piccoli Romanowski, Odete Rocha, Luiz Drude de Lacerda (Org.). PELD CNPq: dez anos do Programa de Pesquisas Ecológicas de Longa Duração do Brasil: achados, lições e perspectivas. 1ed.Recife: Editora Universitária da UFPE, 223-248.

Patterson, E.W., 2016. Stocks and sources of carbon buried in the salt marshes and seagrass beds of Patos Lagoon, Southern Brazil. Honours Theses, 170. Available at: https://scarab.bates.edu/honorstheses/170

Paz, A.R., Reis, L.G.M., Lima, H.V.C., 2005. Uso de modelagem hidrodinâmica visando a segmentação de corpos d'água rasos para enquadramento: o caso do Lago Guaíba (RS). In: XVI Simpósio Brasileiro de Recursos Hídricos, João Pessoa. Anais do XVI SBRH. ISSN 2318-0358.

Pérez, A., Machado, W., Gutiérrez, D., Stokes, D., Sanders, L., Smoak, J.M., Santos, I., Sanders, C.J., 2017. Changes in organic carbon accumulation driven by mangrove expansion and deforestation in a New Zealand estuary. Estuarine, Coastal and Shelf Science 192, 108-116. https://doi.org/10.1016/j.ecss.2017.05.009

Renac, C., Sampaio Mexias, A., Boscato Gomes, M.E., Ronchi, L.E., Stoll Nardi, L.V., Laux, J.H., 2014. Isotopic fluid changes in a Neoproterozoic porphyry-epithermal system: The Uruguay mine, southern Brazil. Ore Geology Reviews 60, 146160. https://dx.doi.org/10.1016/j.oregeorev.2013.12.016

Ribeiro, G.F., Andrade, R, R., Maizonave, C.R.M., 2012. Effects of cyanobacterial summer bloom on the phytoplankton structure in an urban shallow lake, Guaíba Lake, southern Brazil. Neotropical Biology and Conservation 7, 78-87. https://doi.org/10.4013/nbc.2012.72.01

Santos, I.R., Burnett, W.C., Godoy, J.M., 2008. Radionucleids as tracers of coastal processes in Brazil: Review, synthesis, and perspectives. Brazilian Journal of Oceanography 56,115-131. https://dx.doi.org/10.1590/S1679-87592008000200004

Seeliger, U., 2004. Catchment-Lagoon-Estuary-Coast Interactions of the Patos-Mirim System, South Brazil. In: Lacerda, L.D., Santelli, R.E., Duursma, E.K., Abrao, J.J. (Eds). Environmental Geochemistry in Tropical and Subtropical Environments. Springer-Verlag, New York, 384 pp. https://doi.org/10.1007/978-3-662-07060-4_3

Seeliger, U., Costa, C.S.B., 2002. The Patos-Mirim basins, lagoons and estuary: natural and human forcing factors. In: Lacerda, L.D., Kremer, H.H., Kjerfve, B., Salomons, W., MarshallCrossland, J.I., Crossland, J.C. (Eds.), South American Basins: LOICZ Global Change Assessment and Synthesis of River Catchment - Coastal Sea Interaction and Human Dimensions. LOICZ Reports \& Studies 21, 105-112.
RESEARCH PAPER

Silva, P.S.C., Damatto, S.R., Maldonado, C., Fávaro, D.I.T., Mazzilli, B.P., 2011. Metal distribution in sediment cores from São Paulo State Coast, Brazil. Marine Pollution Bulletin 62, 1130-1139. https://doi.org/10.1016/j.marpolbul.2011.02.046

Singh, M., Müller, G., Singh, I.B., 2002. Heavy metals in freshly deposited stream sediments of rivers associated with urbanisation of the Ganga Plain, India. Water Air and Soil Pollution 141, 25-54. https://doi.org/10.1023/A:1021339917643

Skilbeck, C.G., Rolph, T.C., Hill, N., Woods, J., Wilkens, R.H., 2005. Holocene millennial/centennial-scale multiproxy cyclicity in temperate eastern Australian estuary sediments. Journal of Quaternary Science 20, 327-347. https://doi.org/10.1002/jqs.920

Smol, J., 2007. Marine sediments tell it like it was. Proceedings of the National Academy of Sciences PNAS, 104, 17563-17564. https://doi.org/10.1073/pnas.0708635104

Stech, J.L., Lorenzzetti, J.A., 1992. The response of the south Brazil Bight to the passage of wintertime cold fronts. Journal of Geophysical Research 97, 9507-9520. https://doi.org/10.1029/92JC00486

Sutherland, R.A., 2000. Bed sediment-associated trace metals in an urban stream, Oahu, Hawaii. Environmental Geology 39, 611627. https://doi.org/10.1007/s002540050473

Szefer, P., Kusak, A., Szefer, K., Glasby, G.P., Jankowska, H., Wolowicz, M., Ali, A.A., 1998. Evaluation of the anthropogenic influx of metallic pollutants into Puck Bay, southern Baltic. Applied Geochemistry 13, 293-304. https://doi.org/10.1016/S0883-2927(97)00098-X

Teranes, J.L., Bernasconi, S.F., 2005. Factors controlling $\delta 13 \mathrm{C}$ values of sedimentary carbon in hypertrophic Baldeggersee, Switzerland, and implications for interpreting isotope excursions in lake sedimentary records. Limnology \& Oceanography 50, 914 922. https://doi.org/10.4319/lo.2005.50.3.0914

Toldo Jr., E.E., Dillenburg, S.R., Corrêa, I.C.S., Almeida, L.E.S.B., 2000. Holocene Sedimentation in Lagoa dos Patos Lagoon, Rio Grande do Sul, Brazil. Journal of Coastal Research 16, 816-822.

Tomlinson, D.L., Wilson, J.G., Harris, C.R., Jeffrey, D.W., 1980. Problems in the assessment of heavy-metal levels in estuaries and the formation of a pollution index. Helgoländer Meeresunters 33, 566-575. https://doi.org/10.1007/BF02414780

Tribovillard, N., Algeo, T.J., Lyons, T., Riboulleau, A., 2006. Trace metals as paleoredox and paleoproductivity proxies: An update. Chemical Geology 232, 12-32. https://doi.org/10.1016/j.chemgeo.2006.02.012

USEPA (United States Environmental Protection Agency), 1996. Method 3052. Microwave assisted acid digestion of siliceous and organically based matrices. Revision 0 .

Yunes, J.S., Niencheski, L.F.H., Salomon, P.S., Parise, M., Beattie, K.A., Raggett, S., Codd, G.A., 1998. Effect of nutrient balance and physical factors on blooms of toxic cyanobacteria in Patos Lagoon, southern Brazil. Verhandlungen des Internationalen Verein Limnologie 26, 1796-1800. https://doi.org/10.1080/03680770.1995.11901048 